\title{
Effect of Microclimate on Leveillula taurica Powdery Mildew of Sweet Pepper
}

\author{
Yigal Elad, Yoel Messika, Michal Brand, Dalia Rav David, and Abraham Sztejnberg
}

First, second, third, and fourth authors: Department of Plant Pathology and Weed Research, ARO, The Volcani Center, Bet Dagan 50250, Israel; and second, third, and fifth authors: Department of Plant Pathology and Microbiology, Faculty of Agricultural, Food and Environmental Quality Sciences, The Hebrew University of Jerusalem, Rehovot 76100, Israel.

Accepted for publication 21 December 2006.

\begin{abstract}
Elad, Y., Messika, Y., Brand, M., Rav David, D., and Sztejnberg, A. 2007. Effect of microclimate on Leveillula taurica powdery mildew of sweet pepper. Phytopathology 97:813-824.

Sweet pepper-Leveillula taurica microclimate relations were studied under controlled conditions and in commercial greenhouses. Conidial germination occurred at 10 to $37^{\circ} \mathrm{C}$ and was optimal at $20^{\circ} \mathrm{C}$. Conidial viability declined as temperatures increased to $40^{\circ} \mathrm{C}$ for $6 \mathrm{~h}$. Leaf colonization was optimal at 15 to $25^{\circ} \mathrm{C}$. Severe leaf infections occurred at 15 to $20^{\circ} \mathrm{C}$ and conidiation was suppressed at 20 to $25^{\circ} \mathrm{C}$. Highest germination rates were observed at 75 to $85 \%$ relative humidity (RH). Severity of leaf

between 85 to $95 \%$, and positively correlated with nighttime RH. Disease severity was negatively correlated with lengthy periods of temperatures $>25^{\circ} \mathrm{C}$, day and night average temperatures, and average daytime $\mathrm{RH}$. Conversely, leaf shedding was relatively high under conditions characterized by long periods of temperatures $>20^{\circ} \mathrm{C}$ and $<13^{\circ} \mathrm{C}$, and positively correlated with average daytime temperatures and periods of $\mathrm{RH}<75 \%$. Increasing nighttime temperatures by heating and daytime temperatures by closing the greenhouse side walls reduced disease in two commercial greenhouse experiments. A midseason shift from a cooler greenhouse climate to warm daytime climate halted epidemic development. Flower number and yield were reduced in infected crops.
\end{abstract} coverage by symptoms was high for plants which were subjected to longer periods of temperatures between 10 to $15^{\circ} \mathrm{C}$ and daytime $\mathrm{RH}$

Sweet pepper (Capsicum anuum L.) is an important crop in Israel, grown on 2,240 ha in greenhouses and net houses. Powdery mildew, caused by Leveillula taurica (Lév.) G. Arnaud, is a major problem in this crop (16). Until the early 1990s, pepper powdery mildew was known as a disease of warm-climate regions; however, in recent years, it has become a problem in Western Europe, North America, and other temperate regions, probably as a result of the expanded use of heated greenhouses for pepper production $(5,6)$. In Israel, this disease has been known for several decades. In greenhouses, the disease first appears early in the growing season and can destroy the entire crop if not treated.

The endoparasite $L$. taurica in pepper develops differently than the 'classical ectoparasitic' powdery mildew fungi. Part of its life cycle takes place inside the leaf, whereas other powdery mildew fungi grow only on the leaf surface and form haustoria through which they feed on the plant. After germinating, the germ tube of L. taurica conidia grows on the leaf surface until it encounters a stoma through which it can enter the plant $(4,13)$. After artificial inoculation, $70 \%$ of the conidia germinate within $3 \mathrm{~h}$ (10). After penetration, the fungus grows intercellularly inside the leaf for up to 3 to 4 weeks (11). Then, the mycelium grows out of the leaf through the stomata, and conidiophores with conidia are formed on the leaf surface (11). This conidiation is visible as white colonies. Most of the visible symptoms can be found on the lower leaf surface, either because of the higher density of stomata on this side or because the microclimate there is more suitable for disease development. Typical symptoms sometimes may appear on the upper side of the leaf as well. Light yellow spots occur on the upper surface while white colonies grow on the lower surface.

Corresponding author: Y. Elad; E-mail address: elady@ volcani.agri.gov.il

doi:10.1094/PHYTO-97-7-0813

(c) 2007 The American Phytopathological Society
Additional keywords: biomass, germ tube.
Powdery mildew colonies may coalesce during severe epidemics (15). A major problem in this pathosystem is the fact that pepper leaves are shed when they are infected by powdery mildew. This means that the lost photosynthetic area is greater than the area covered by powdery mildew colonies. Once leaves are shed, the fruit are exposed to direct irradiation and are damaged due to sunburn. This disease can cause severe damage to pepper plants and the pathogen is difficult to control because a major part of its life cycle takes place inside the leaf (16).

Reuveni and Rotem (18) found that the optimal temperature for the germination of conidia of $L$. taurica is $25^{\circ} \mathrm{C}$. At temperatures $>25^{\circ} \mathrm{C}$, the rate of germination is reduced and germ tube development is slowed. Conidia usually do not germinate at temperatures $>30^{\circ} \mathrm{C}$ (3). Schnathorst (19) classified L. taurica among the powdery mildews that optimally germinate at 96 to $99 \%$ relative humidity $(\mathrm{RH})$ and suboptimally $>50 \% \mathrm{RH}$, though some minor germination can occur below this level of RH. Similarly, Caesar and Clerk (2) found that germination and germ tube elongation increase gradually at RH values between 0 and $100 \%$.

Data on the epidemiology of pepper powdery mildew are limited and not very recent. Reuveni and Rotem (18) found that, in Israel, epidemics were more severe in pepper under humid conditions than under dry conditions. Diop-Bruckler (7) found that this effect of humidity may be reversed in different cultivars. The optimum temperature for L. taurica development in pepper is $20^{\circ} \mathrm{C}$ and no disease occurs $>30^{\circ} \mathrm{C}$ (17). Leaf shedding is more severe at temperatures between 10 and $20^{\circ} \mathrm{C}$ than at $25^{\circ} \mathrm{C}$, but increases again at $30^{\circ} \mathrm{C}(17)$. At high temperatures, symptomless leaves also are shed (17). It was reported that the incidence of the disease on pepper and tomato leaves was higher when nighttime $\mathrm{RH}$ levels were high (17). Other researchers found the highest levels of leaf shedding at lower RH levels (18). The damage relationship for L. taurica in pepper has not been established. In tomato, this fungus can causes $31 \%$ yield losses (12). 
Pepper powdery mildew is controlled through the use of fungicides, including sulfur. The current recommendation is for frequent applications beginning early in the season. In Israel, pepper growers have switched in recent years to intensive spraying with sulfur products; however, other chemical products also are available. Sulfur may have adverse side effects on beneficial insects and, therefore, other control methods need to be developed. In order to develop an effective, integrated system for managing pepper powdery mildew, we needed to examine more closely the effects of temperature and $\mathrm{RH}$ on the disease. We hypothesized that, by manipulating the crop microclimate within commercial greenhouses, we might be able to slow the progress of the disease and reduce the need for chemical control measures.

\section{MATERIALS AND METHODS}

Pathogen and host plants. L. taurica was isolated from young leaves of sweet pepper plants grown in a commercial greenhouse at the Besor Research and Development Station, western Negev, Israel. Conidia of the pathogen were collected by rinsing infected leaves with sterile water and were counted under a light microscope using a hemacytometer. For the artificial infection of pepper leaves (laboratory and growth-chamber experiments), the concentrations of these conidia suspensions were adjusted to $10^{6} / \mathrm{ml}$ and the suspensions were sprayed onto plants at a volume of $2 \mathrm{ml} / \mathrm{plant}$, within 10 to $15 \mathrm{~min}$ of the initial conidia collection.

Pepper plants (cv. Mazurka, unless otherwise noted) were obtained from a nursery (Shorashim, Moshav Ein Habesor) at 40 to 50 days after planting and transplanted into 1-liter pots containing peat:vermiculite $(1: 1, \mathrm{vol} / \mathrm{vol})$ growth mixture supplemented with $50 \mathrm{~g}$ of 17:20:27 NPK slow-release fertilizer (Osmocot; Scotts-Sierra Horticulture, Marysville, $\mathrm{OH})$. Plants were irrigated every 1 to 3 days, allowing for $30 \%$ drainage. Plants were maintained at 20 to $25^{\circ} \mathrm{C}$ in a pest-free, disease-free greenhouse for 4 to 5 weeks prior to the initiation of the experiments. Experiments were initiated after plants had reached the five-node developmental stage.

For the germination experiments, conidia were spread on glass slides at $\approx 10^{3}$ conidia $/ \mathrm{cm}^{2}$ by agitating mildew-bearing leaves above the slides. The slides were incubated for $6 \mathrm{~h}$ at seven different temperatures (i.e., 10, 15, 20, 25, 30, and $37^{\circ} \mathrm{C}$ ) and $85 \%$ $\mathrm{RH}$ in closed boxes ( 20 by 15 by $30 \mathrm{~cm}$ ). Other slides were kept at a constant temperature $\left(20^{\circ} \mathrm{C}\right)$ and six different $\mathrm{RH}$ levels. The different $\mathrm{RH}$ conditions were created by placing the glass slides above different saturated salt solutions. The solutions used were ( $\mathrm{RH}$ in parentheses) $\mathrm{LiCl}(11 \%), \mathrm{MgCl}_{2}(33 \%), \mathrm{KNO}_{2}(49 \%)$, $\mathrm{NaCl}(75 \%), \mathrm{KCl}(85 \%)$, and no salt $(99 \%)$. Conidial germination was observed using a light microscope. The length of the germ tubes and the percentage of germination were recorded for 50 conidia per slide in 10 slide replicates.

The conidia placed on glass slides, as described above, also were used to study conditions affecting viability, and the tests are described below. The slides were incubated for $6 \mathrm{~h}$ at 10, 15, 20, $25,30,35$, and $40^{\circ} \mathrm{C}$ and $75 \% \mathrm{RH}$. Following the incubation period, conidia were washed off the slides with water and glucose was added to the water-conidia suspension at a concentration of $200 \mathrm{mg} / \mathrm{ml}$. The suspension was centrifuged for $5 \mathrm{~min}$ at 10,000 $\mathrm{rpm}$. The conidia then were resuspended in a glucose solution of $200 \mathrm{mg} / \mathrm{ml}$ with $160 \mu \mathrm{l}$ of $10 \mu \mathrm{M}$ Na-HEPES buffer, calcofluor in water at $10 \mathrm{mg} / \mathrm{ml}$, and $40 \mu \mathrm{l}$ of $1 \%$ FUN1 solution. The FUN1 solution consisted of $10 \mathrm{mM}$ 2-chloro-4-(2,3-dihydro-3-methyl\{benzo-1,3-thiazol-2-yl\}-methylidene)-1-phenylquinolinium iodide (Molecular Probes, Eugene, OR) and Na-HEPES and was kept in the dark. The suspensions were agitated in the dark at $50 \mathrm{rpm}$ and $28^{\circ} \mathrm{C}$ for $90 \mathrm{~min}$. Drops of the conidial suspensions then were placed on glass slides and observed under a fluorescent microscope $(480 \mathrm{~nm})$. Under the fluorescent microscope, live (respirat- ing) conidia emit red radiation, whereas dead conidia emit greenyellow radiation with no red dots (14).

Hyphae colonization inside leaf tissues was tested in excised leaves taken from growth-chamber experiments with different microclimate conditions as described in the results section. Leaf samples were washed with tap water to remove dust and aerial powdery mildew mycelium and then submerged in a discoloration solution consisting of formalin, acetic acid, and ethanol (1:1:1, $\mathrm{vol} / \mathrm{vol}$ ) for $72 \mathrm{~h}$ at $50^{\circ} \mathrm{C}$. The discolored leaves then were incubated in lacto-glycerin (lactic acid, glycerin, and water, 1:1:1, $\mathrm{vol} / \mathrm{vol}$ ) for $24 \mathrm{~h}$ at $50^{\circ} \mathrm{C}$. Two $2-$ by-3-cm pieces were sampled from each of 10 sampled leaves, placed on glass slides, and observed under a light microscope. Hyphae length was evaluated using a graded eye piece.

In order to measure conidiation, 2-by-3-cm leaf pieces, each sampled from 10 leaves, were washed in $10 \mathrm{ml}$ of $0.01 \%$ Tween 80 solution. The wash suspension was centrifuged at 5,000 rpm and the pellet was resuspended in $10 \mathrm{ml}$ of water. The number of conidia in the final suspension was counted under a light microscope.

Growth chamber experiments. The effects of temperature and RH on powdery mildew development were tested on pepper plants incubated in growth chambers (Conviron Products, Winnipeg, Canada) at conditions as described for each experimental set in the Results section. Conditions in the growth chambers were set to fluctuate between specified minimum night and maximum day temperatures. All treatments received the same light regime. The lights were first turned on at 06:00 and increased in intensity in four steps until 09:00. The lights declined in their intensity from 16:00 until they were completely turned off at 19:00. RH in the temperature experiments was kept between 80 and $90 \%$. RH experiments were conducted at $20 \pm 1{ }^{\circ} \mathrm{C}$. Temperature and $\mathrm{RH}$ were recorded hourly using data loggers (Hobo; Onset Computer Corp., Pocasset, MA). Five groups of four plants each served as replicates in the growth-chamber experiments.

Commercial greenhouses-general. Sweet pepper plants were planted in sandy soil each year between 1 and 5 September in 1997 through 2001. The plants were grown to one stem and then attached to ropes hanging from the ceiling of the greenhouses. The first blooms were removed soon after their appearance, as practiced in Israel. The plants were maintained according to local, commercial standards. Each season, two applications of $0.05 \%$ Vertimec (abamectin at EC $18 \mathrm{~g} / \mathrm{liter}$; Syngenta, Basel, Switzerland) were sprayed to control European red mite (Panonychus ulmi) and broad mite (Polyphagotarsonemus latus). One application of $0.04 \%$ Tracer (spinosad at SC $240 \mathrm{~g} /$ liter; Dow Agrosciences LLC, Indianapolis) was sprayed each season for the control of Western flower thrips (Frankliniella occidentalis). Diseases other than powdery mildew did not occur in the greenhouse plots.

Disease. L. taurica infection occurred naturally every growth season. No fungicides were applied during the entire season. The disease in the commercial greenhouses first appeared in October of each year. Disease severity was evaluated every 2 to 3 weeks, unless otherwise mentioned. There were 20 plants in each plot, unless otherwise specified, and 10 centrally located plants were rated for disease severity. Leaves at different heights were evaluated for the determination of percentage of coverage with powdery mildew symptoms. The severity (percentage) of leaf coverage (PLC) in each plot was calculated by averaging the severity values at different plant heights. One leaf was sampled in each plant height over the 10 sampled plants in each plot. The number of shed leaves (NSL) on the ground per plot was counted at each evaluation point and the leaves were removed. Total disease severity $($ TDS $)$ was calculated as TDS $=$ NSL/NLP $\times 100+(1-$ NSL/NLP) $\times$ PLC, where NLP $=$ total number of leaves. This formula originally was developed by Shtienberg and Dreishpoun (20). Fruit were picked every 2 weeks, sorted by quality $(\mathrm{A}=$ 
export quality, $\mathrm{B}=$ local market quality, and $\mathrm{C}=$ distortions), counted, and weighed.

Microclimate measurements. Air temperatures, leaf temperatures, and RH values were recorded hourly in the greenhouses using data loggers with thermocouplers and RH sensors (Campbell Scientific Inc., Logan, UT). These data were adjusted for dew presence and vapor pressure deficit (VPD). Microclimate parameters were analyzed on a weekly basis in two ways: (i) average night- and daytime temperatures for each week and average daily temperature, RH, and VPD levels; and (ii) weekly averages of the duration (h) of temperature (in $5^{\circ} \mathrm{C}$ intervals), duration of $\mathrm{RH}$ levels (in 5\% intervals), and duration of dew presence. Correlations between the abovementioned climate parameters and the powdery mildew levels over different periods during the growing season were calculated.

Greenhouses. Two types of greenhouses were used at the Besor R\&D Research Station. (i) One large (1,000 $\left.\mathrm{m}^{2}\right)$ structure consisted of 12 bays. Three rows of plants were planted in each bay. A heater blowing warm air was placed along the southern wall of the greenhouse to warm the greenhouse air. Perforated polyethylene sleeves spread the warm air along the gaps between each row, distributing the warm air in the greenhouse. Heating began in mid November of each year when night temperatures fell below $15^{\circ} \mathrm{C}$. (ii) Small greenhouses $\left(250 \mathrm{~m}^{2}\right)$ each were planted with six rows $18 \mathrm{~m}$ long. An irradiative heating system, in the form of pipes carrying warm water around each row, was used when cool weather necessitated nighttime heating of the small greenhouses.

Effects of climate and cultivar on disease (field experiment 1, 1997-98). Three cultivars (Turkal, Mazurka, and Kumbia) each were planted in three rows in each of four bays in the large experimental greenhouse. The heater was placed along the southern wall of the greenhouse and warm air was blown along the rows. The southern greenhouse wall was kept closed during the heating hours (typically 20:00 to 08:00 $\pm 2 \mathrm{~h}$, depending on outside temperatures). The northern wall of the greenhouse was kept partially open in order to allow cold air to penetrate. This resulted in temperature gradient along the rows, with nighttime lows between 13 and $16^{\circ} \mathrm{C}$. Four sampling plots were placed along the rows, with the southern subplots characterized by warmer nighttime temperatures. The plots along the temperature gradient were marked as A, B, C, and D, where A plots were the most southern and, therefore, had the warmest nighttime temperatures. This design allowed us to evaluate disease symptoms and yield in three cultivar by four climate regimes, each in four replicates.

Effect of climate on disease (field experiment 2, 1998-99). Sweet pepper plants were planted in the large experimental greenhouse. The greenhouse was heated to ensure nighttime lows of $17^{\circ} \mathrm{C}$ in the western half of the greenhouse and $12^{\circ} \mathrm{C}$ in the eastern half. In order to increase the $\mathrm{RH}$ in the southern half of the greenhouse, the air above the canopy was misted. No additional moisture was provided in the northern half of the greenhouse. Each of the four RH-temperature environments consisted of five plots, with three rows in each plot. Each row was $15 \mathrm{~m}$ long with 30 plants.

Effect of side-wall aeration and greenhouse cover on disease (field experiment 3, 1998-99). This experiment was carried out in 12 small, polyethylene-covered, unheated greenhouses at the Besor Research Station. Variations in greenhouse climate were created by changing the side wall aeration during the daytime, using insect protection nets with 30 to 50 mesh. Polyethylene was used to cover the side walls during the night. Crop management was similar to that of the first experiment, except for the heating. The roof of the greenhouses was covered with infrared repellent polyethylene with higher (IRV) or lower (IRR) ultraviolet (UV) protection. There were six 15 -m-long plots within each climate regime, and four greenhouse replicates per climate. The standard commercially used greenhouses are equipped with IRR polyethylene cover and 50 mesh side walls.

Effect of microclimate change on powdery mildew (field experiment 4, 1999-2000). Sweet pepper plants (cvs. Mazurka and Cubi) were grown in eight small greenhouses over a 9-month season that was split into two periods (Table 1). In each period, there were two daytime microclimate treatments, each in four greenhouses. Increased daytime temperatures were obtained by keeping the side walls closed during the day, as compared with the common practice of opening the side walls during the day. Higher and lower nighttime temperatures were obtained by irradiative heating (Table 1). The daytime temperature regime was rotated between the greenhouses in the shift between the two time periods. Six 15-m-long plots were assigned to each microclimate regime.

Climate management for powdery mildew suppression (field experiment 5, 2000-01). This experiment was carried out in the small greenhouses with pepper cv. Selika. Two climate regimes, each in four greenhouses, were maintained as follows: (i) warm climate: daytime temperatures of 25 to $32^{\circ} \mathrm{C}$ were achieved by rolling down the side polyethylene walls during the day and a nighttime temperature of $18^{\circ} \mathrm{C}$ was maintained by heating during the cold season of January through March; and (ii) cool climate: daytime temperatures were kept at 15 to $25^{\circ} \mathrm{C}$ by opening the side walls, as commonly practiced by farmers, and heating was used to maintain a nighttime temperature of $15^{\circ} \mathrm{C}$ from January through March.

Statistical analysis. Powdery mildew severity (leaf coverage) was averaged per plant and then per plot. Leaf shedding was counted per plot and calculated for a single plant by dividing with the plant number. TDS was calculated in percentage as detailed above. Data in percentages were arcsin transformed. The area under the disease progress curve (AUDPC) was calculated in some cases. Linear regression analysis was used to compare yield data and AUDPC data. Linear regression also was used to evaluate the relationships between disease parameters and temperature and RH data. Nonlinear regression analyses also were carried out, but they did not result in better a description of the relationships between parameters compared with linear regressions. Correlation results are presented when significant; presented are coefficient values or whether relationships between parameters are positively or negatively correlated. In the Results section, AUDPC, total fruit yield, and percentage of first-class fruit data were analyzed using analysis of variance and Fisher's protected least significant difference tests. Standard errors of the mean yields in field experiment 3 were calculated. Effects of temperature or RH on germination and viability of conidia were determined by regression

TABLE 1. Microclimate regimes (field experiment 4, 1999-2000) ${ }^{\mathrm{x}}$

\begin{tabular}{|c|c|c|c|c|c|c|}
\hline \multirow{4}{*}{$\frac{\text { Greenhouse no. }}{1 \text { to } 3}$} & \multicolumn{2}{|c|}{ First period: October-December 1999} & \multicolumn{4}{|c|}{ Second period: January-May 2000} \\
\hline & \multirow{2}{*}{$\begin{array}{l}\text { Avg. day }\left({ }^{\circ} \mathrm{C}\right)^{\mathrm{y}} \\
\text { Unheated }(18)\end{array}$} & \multirow{2}{*}{$\begin{array}{c}\text { Night }^{\mathrm{z}} \\
\text { Unheated }\end{array}$} & \multirow{2}{*}{$\frac{\text { Day }}{\text { Heated (25) }}$} & \multicolumn{3}{|c|}{ Minimum nighttime temperatures $\left({ }^{\circ} \mathrm{C}\right)^{y}$} \\
\hline & & & & 13 & 18 & 22 \\
\hline & Heated (25) & Unheated & Unheated & 13 & 18 & 22 \\
\hline
\end{tabular}

${ }^{x}$ All temperatures are $\pm 2{ }^{\circ} \mathrm{C}$.

y Average daytime temperatures.

${ }^{\mathrm{z}}$ Nighttime minimal temperatures were $17.1,15.3$, and $12.9^{\circ} \mathrm{C}$ in October, November, and December, respectively; no night heating was implemented. 
analyses. Disease levels were statistically separated following one-way analysis of variance and the least significant differences are marked in figures using bars. Statistical analysis was done with the JMP software (SAS Institute, Cary, NC).

\section{RESULTS}

Effects of temperature and $\mathrm{RH}$ on germination and survival of conidia and the establishment of hyphae inside leaf tissues. Conidial germination on glass was evaluated at 10 to $37^{\circ} \mathrm{C}$ and 10 to $99 \% \mathrm{RH}$. The highest rate of germination was observed at $20^{\circ} \mathrm{C}$. The rate of germination declined at temperatures of $\leq 15^{\circ} \mathrm{C}$ and $\geq 25^{\circ} \mathrm{C}$ (Fig. 1). With temperature held constant at $20^{\circ} \mathrm{C}$, germination was the highest at 85 to $99 \% \mathrm{RH}$ and lowest at $10 \%$ RH (Fig. 2).

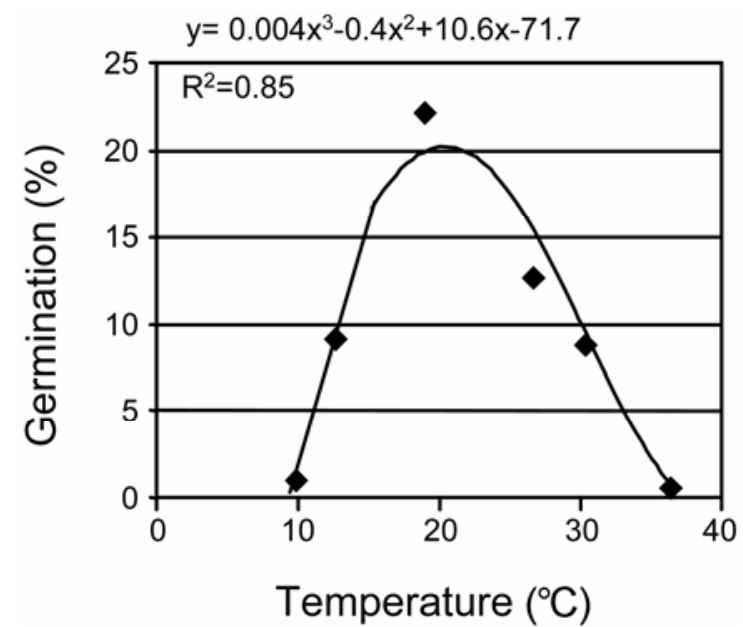

Fig. 1. Effect of temperature on germination of Leveillula taurica conidia on glass slides incubated for $6 \mathrm{~h}$ at various temperatures and $85 \%$ relative humidity.
The growth of L. taurica inside the leaf tissue was tested at day and night temperatures of 15 and 10,20 and 15 , and 25 and $20^{\circ} \mathrm{C}$, respectively. The least growth was observed at the lowest temperatures and more growth was observed at the warmer day and night temperatures (Table 2). The number and size of fungal hyphae inside the leaf tissue was evaluated following incubation under sets of temperature conditions for the infection (first day after infection) and growth inside the leaf tissue (13 following days were 20 and 25,25 and 25,20 and 30 , and 30 and $30^{\circ} \mathrm{C}$, respectively (Table 3 ). The lengths of observed hyphae were the lowest for the 30 -and $-30^{\circ} \mathrm{C}$ treatment and the number of hyphae fragments was lower for the 30 -and- 30 and 20 -and- $30^{\circ} \mathrm{C}$ treatments. The smallest overall biomass quantities were found inside the leaves that were incubated under the 30 -and $-30^{\circ} \mathrm{C}$ conditions (Table 3 ). A significant positive correlation between hyphae biomass in the leaves and disease severity was observed (data not shown).

The formation of conidia on leaves infected by L. taurica at RH 85 and $95 \%$ (day and night) was not different from the conidiation at 60 and $85 \%$ day and night RH (data not shown).

Observations of conidia following a 6-h incubation at temperatures between 10 and $40^{\circ} \mathrm{C}$ showed that conidia survival rates declined linearly as temperatures rose (Fig. 3).

TABLE 3. Establishment of Leveillula taurica in leaf tissues following temperature regimes during the first day and 13 following days and measured 14 days following inoculation ${ }^{\mathrm{z}}$

\begin{tabular}{lccccc}
\hline \multicolumn{2}{l}{ Temperature $\left({ }^{\circ} \mathrm{C}\right)$} & & \multicolumn{3}{c}{ Hyphae } \\
\cline { 1 - 2 } \cline { 5 - 6 } Initial & 13 days later & & No./cm ${ }^{2}$ of leaf & Length $(\mu \mathrm{m})$ & Biomass $\left(\mu \mathrm{m} / \mathrm{cm}^{2}\right)$ \\
\hline 20 & 25 & & $2.9 \mathrm{a}$ & $1,250 \mathrm{a}$ & $3,625 \mathrm{a}$ \\
25 & 25 & & $3.7 \mathrm{a}$ & $1,760 \mathrm{a}$ & $6,512 \mathrm{a}$ \\
20 & 30 & & $0.8 \mathrm{~b}$ & $1,460 \mathrm{a}$ & $1,168 \mathrm{~b}$ \\
30 & 30 & $0.2 \mathrm{~b}$ & $350 \mathrm{~b}$ & $70 \mathrm{c}$ \\
\hline
\end{tabular}

${ }^{\mathrm{z}}$ Numbers in each column followed by a common letter are significantly not different according to Fisher's protected least significant difference test $(P \leq$ $0.05)$.

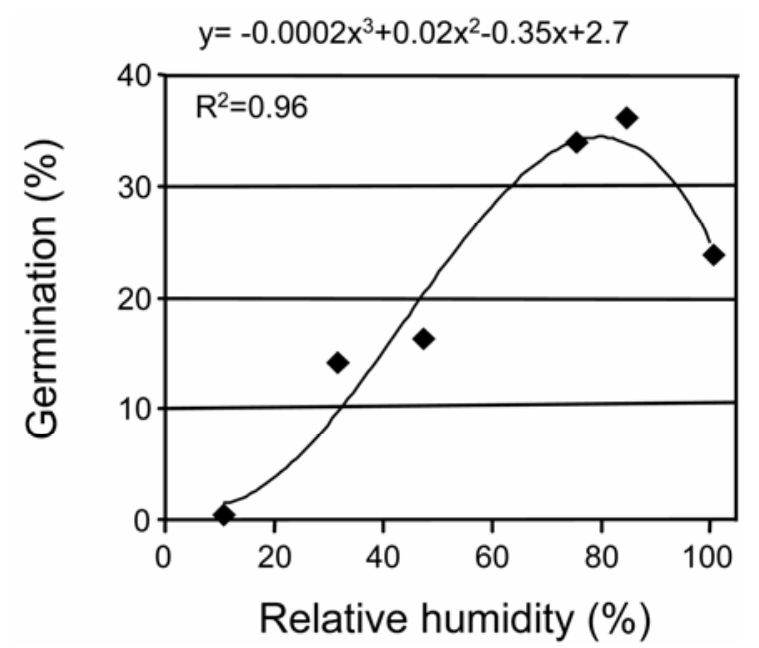

Fig. 2. Effect of relative humidity $(\mathrm{RH})$ on germination of Leveillula taurica conidia on glass slides incubated for $6 \mathrm{~h}$ at $20^{\circ} \mathrm{C}$ and different $\mathrm{RH}$ levels.

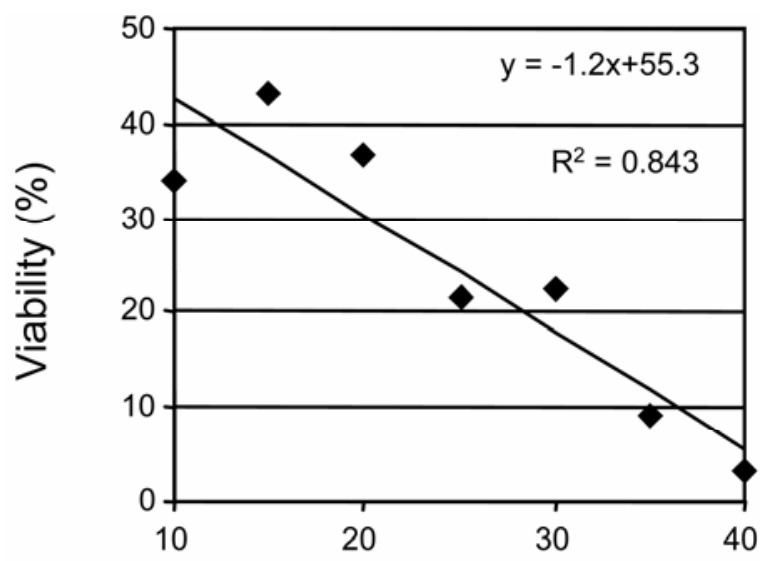

Temperature $\left({ }^{\circ} \mathrm{C}\right)$

Fig. 3. Survival of conidia of Leveillula taurica incubated for $6 \mathrm{~h}$ at various temperatures and $75 \%$ relative humidity.

TABLE 2. Establishment of Leveillula taurica in leaf tissues under different day and night temperature regimes, evaluated at 7 and 14 days after inoculation ${ }^{z}$

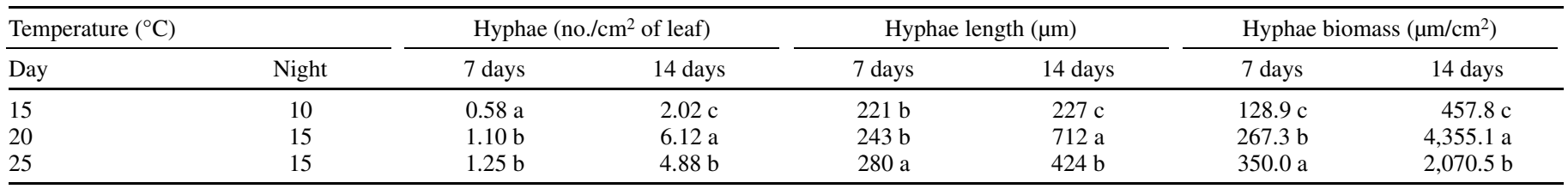

${ }^{\mathrm{z}}$ Numbers in each column followed by a common letter are significantly not different according to Fisher's protected least significant difference test $(P \leq 0.05)$. 
Effect of temperature regimes on disease severity. Plants were incubated at day/night temperatures of 15 and 10, 20 and 15, and 25 and $20^{\circ} \mathrm{C}$. The most severe disease was seen in the plants kept under moderate $\left(20\right.$ and $\left.15^{\circ} \mathrm{C}\right)$ temperature conditions and the lowest levels of disease were seen at the higher temperatures of 25 and $20^{\circ} \mathrm{C}$ (Fig. 4).

Sets of temperature conditions for the infection (1 day after inoculation) and following the establishment period (14 days after inoculation) were 20 and 20,20 and 25, 20 and 30, 25 and 25, and 30 and $30^{\circ} \mathrm{C}$, (first day and 14 following days, respectively). Disease severity after 30 days was grouped into three levels significantly different from each other as follows: $4.6 \%$ after incubation at 20 and $20^{\circ} \mathrm{C} ; 9.9$ and $10.8 \%$ following incubation at 20 and 25 and 25 and $25^{\circ} \mathrm{C}$, respectively; and 2.3 and $0 \%$ when incubated at 20 and 30 and 30 and $30^{\circ} \mathrm{C}$, respectively.

Incubation of plants at different $\mathrm{RH}$ levels between 60 and $95 \%$ resulted in similar levels of disease on whole pepper plants (data not shown).

Effects of climate and cultivar on disease (field experiment 1, 1997-98). Our first experiment under commercial conditions was done in a greenhouse with temperature gradients along rows of the three sweet pepper cvs. Turkal, Mazurka, and Kumbia. Disease first appeared on the older leaves of the three cultivars at the beginning of October, 37 days after planting. By December (120 days after planting), symptoms had already reached leaves attached to the sixth and seventh nodes. Disease was more severe on older leaves than younger leaves (Fig. 5). Generally, the amount of leaf surface covered by powdery mildew was significantly $(P \leq 0.05)$ higher for $\mathrm{cv}$. Kumbia and significantly $(P \leq$ 0.05 ) lower for cv. Turkal (data not shown), indicating a difference in susceptibility to leaf infection among pepper cultivars. Shed leaves, as a result of powdery mildew infection, were first noted in January (148 days after planting) (shown only for cv. Turkal) (Fig. 6B). At that time (148 to 176 days after planting), the amount of leaf surface covered by the mildew was at its peak. It then began to decline as older, infected leaves were shed and new leaves were infected at a slower rate (Fig. 6A). The Kumbia plants shed the most leaves and the Mazurka plants shed the least (data not shown). The calculated TDS gradually increased until the end of the season due to accumulation of shed leaves (Fig. 6C to E). Disease was least severe in cv. Turkal.

Because the effects of microclimate variation on leaf coverage by the pathogen and leaf shedding seemed to be different, the correlations between these two parameters in the different plots were calculated. A positive and significant correlation between these two disease parameters was obtained only in plots located in

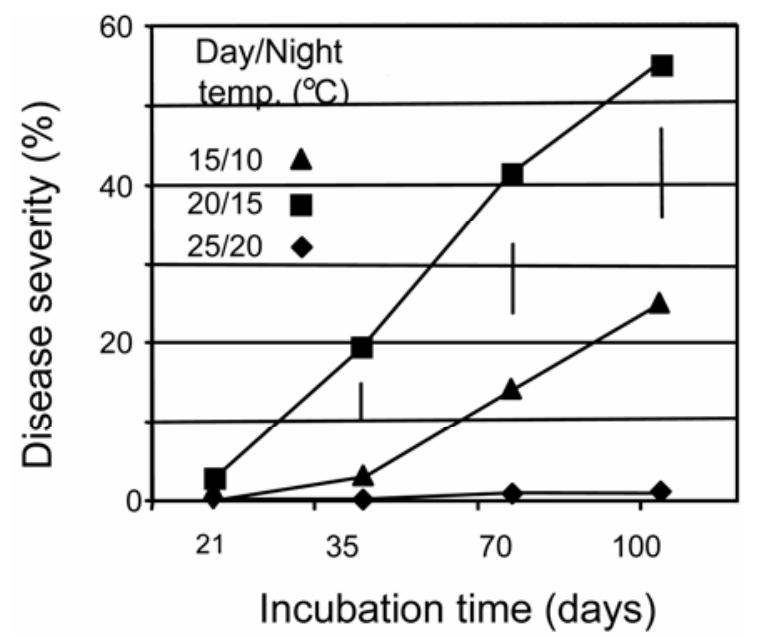

Fig. 4. Extent of leaf coverage by powdery mildew on sweet pepper plants incubated in growth chambers with varying day and night temperatures. Bars represent the least significant differences (at $P \leq 0.05$ ) for each date. regions $\mathrm{A}$ and $\mathrm{B}$ (the warmer areas) for two of the three cultivars. In both of these cultivars (Turkal and Kumbia), the correlation coefficients obtained for whole-season leaf infection versus leaf shedding that had occurred in the second half of the season were 0.981 and 0.889 , respectively. The correlation coefficients obtained in the two cultivars for leaf infection that occurred in the first half of the growth season and affected the leaf shedding during the second half of the season were 0.949 and 0.939 , respectively.

Greenhouse temperatures during the period of disease development ranged from 10 to $27^{\circ} \mathrm{C}$ and $\mathrm{RH}$ was consistently $>50 \%$. Plots located in regions A and B had one distinct set of temperature and $\mathrm{RH}$ conditions, whereas plots in regions $\mathrm{C}$ and $\mathrm{D}$ had another. Average nighttime temperatures in the plots located in regions $\mathrm{A}$ and $\mathrm{B}$ were typically 2 to $3^{\circ} \mathrm{C}$ higher than those in regions $\mathrm{C}$ and $\mathrm{D}$. At the same time, the average $\mathrm{RH}$ levels in the $\mathrm{A}$ and B plots were 5 to $10 \%$ lower than those of the C and D plots. Plots with higher levels of disease typically were characterized by longer periods of 10 to $15^{\circ} \mathrm{C}$ and $>80 \% \mathrm{RH}$ levels than plots with lower levels of disease (Table 4).

Correlations between microclimate data and disease severity in the different plots were calculated (Table 5). The durations of the different RH and temperature levels are described in Table 4. Duration of high RH (>80 to $90 \%$ ) was positively correlated with leaf coverage by powdery mildew for two of the three cultivars. Higher temperature was negatively correlated with these symptoms on all cultivars. High levels of leaf shedding were observed at $\mathrm{RH}$ levels $>60$ to $70 \%$ (Table 5).

Crop yields varied by cultivar, plot location, and harvest date (data not shown). Powdery mildew was negatively correlated with yield of cv. Turkal in the cooler plots of regions $\mathrm{C}$ and $\mathrm{D}$ but not in the warmer plots (A and B). Plots of regions C and D were characterized by high disease severity. No correlation between disease and yield was observed in cv. Kumbia. Positive correlation between disease and yield was observed in the warmer plots (A and B) of cv. Mazurka. In contrast, in the cooler plots (regions $\mathrm{C}$ and D) that harbored higher disease severity, yield of this cultivar was negatively correlated with disease.

Effect of climate on disease (field experiment 2, 1998-99). Greenhouses were heated at night to establish regions of high and low minimum night temperatures. Within each of the two temperature treatments, there were two humidity treatments. Powdery mildew due to natural infection first appeared on lower leaves in the beginning of November. Leaf coverage in the northern plots increased gradually, reaching 94\% 140 days after planting, followed by a drastic decline. In these plots, there was significant leaf shedding during January. In the southern plots, leaf coverage

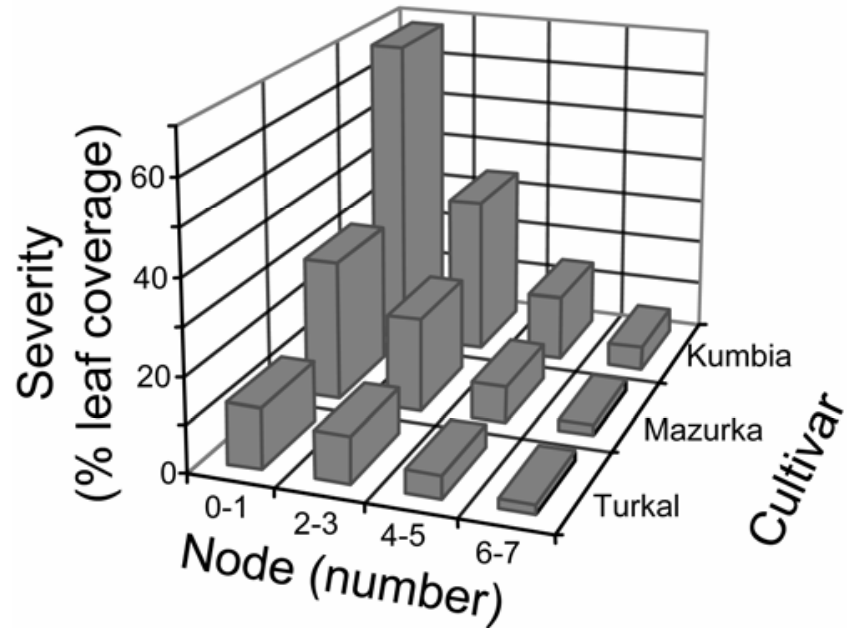

Fig. 5. Severity of powdery mildew symptoms on three cultivars of sweet pepper in a commercial greenhouse (field experiment 1). Coverage of leaves at four plant heights. 
reached 40 to $45 \% 140$ days after planting and declined 50 days later (Fig. 7A). Leaf shedding was lower in these plots and developed gradually throughout the growing season (Fig. 7B). TDS data are presented in Figure 7C.
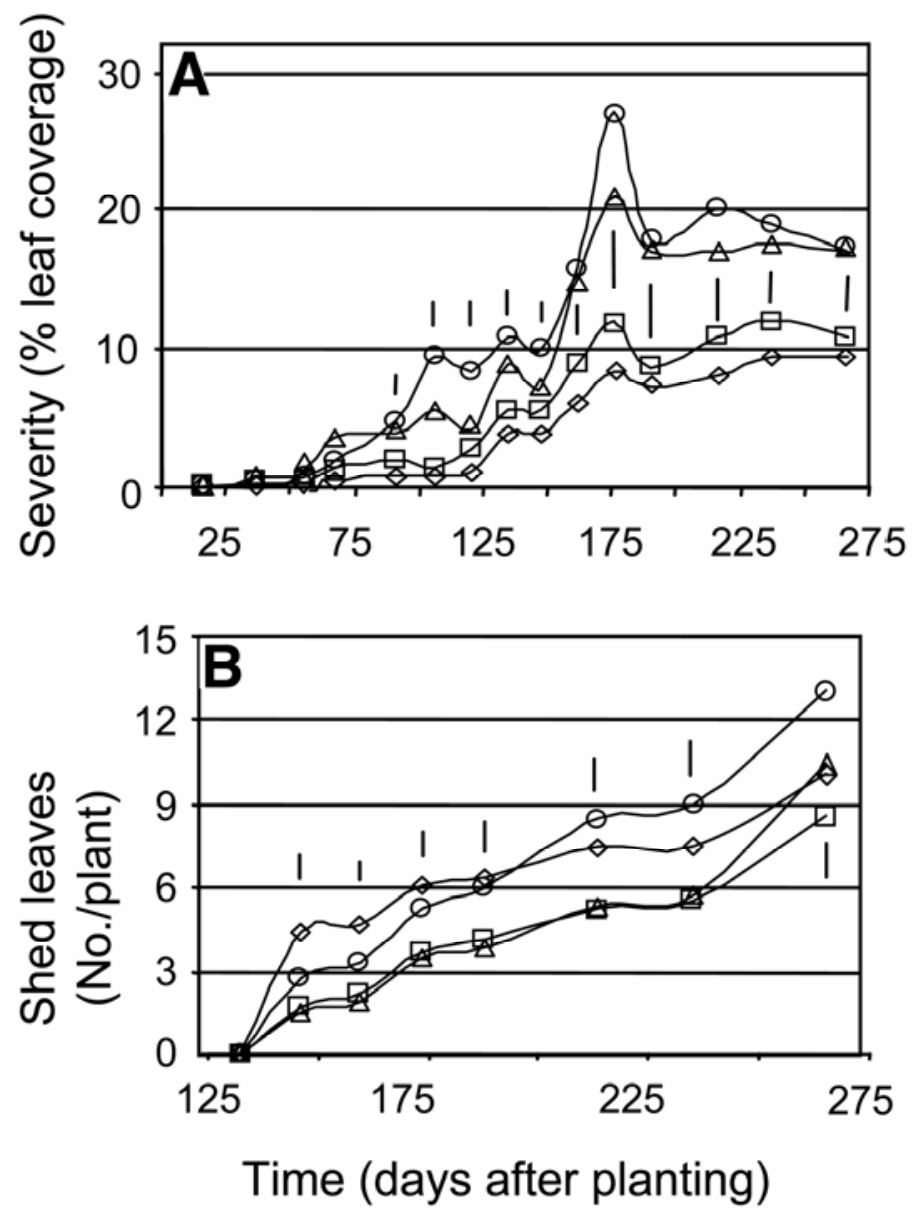

Disease levels were significantly lower in the southern plots. The more noticeable microclimatic features of these plots were longer periods of VPD $>0.5 \mathrm{KPa}$ and temperatures from 19 to $25^{\circ} \mathrm{C}$. Additionally, shorter periods of VPD of 0.6 to $1.5 \mathrm{KPa}$,
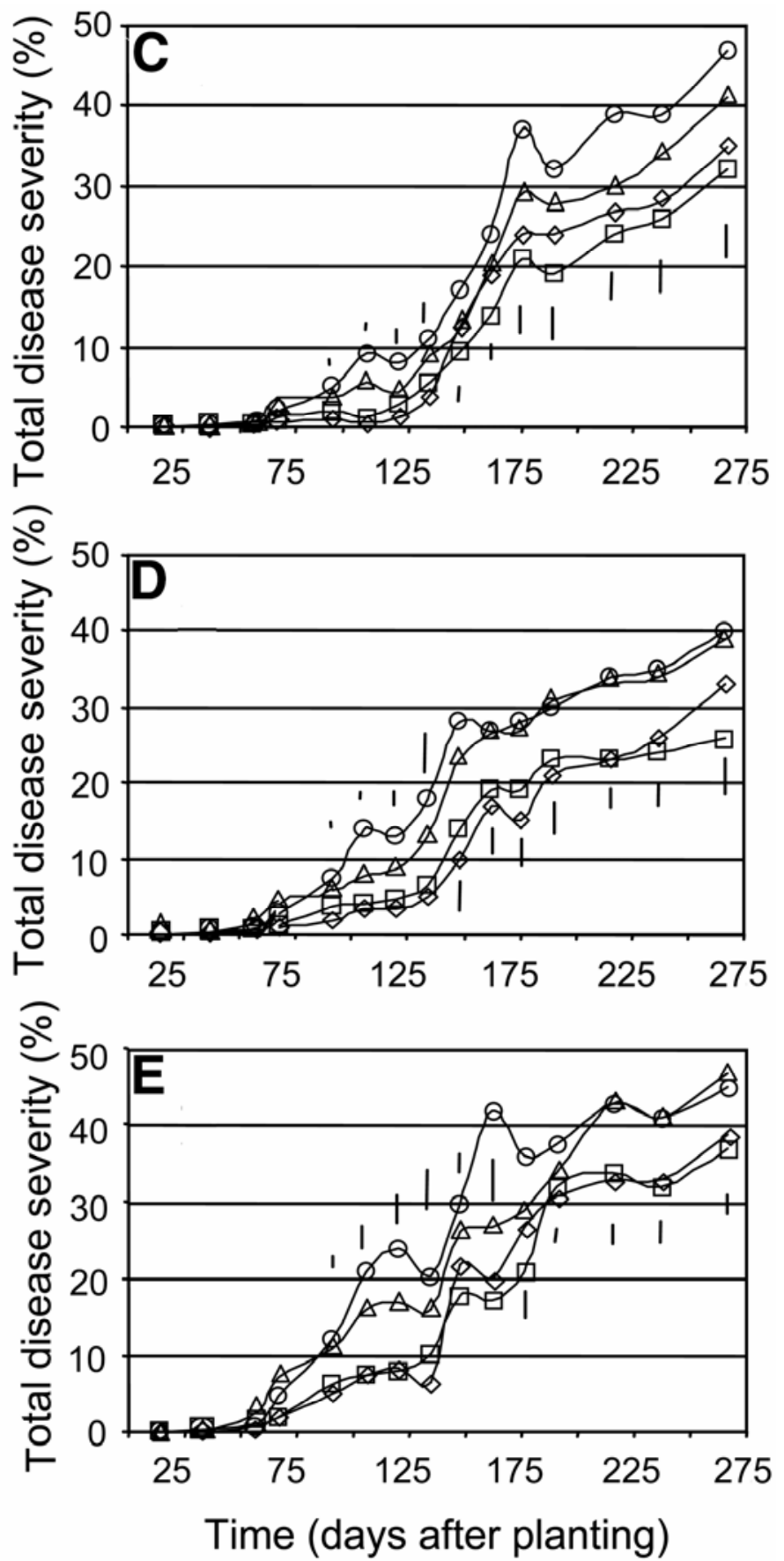

Fig. 6. Effects of cultivar and minimal nighttime temperature on the development of powdery mildew on sweet pepper plants in a commercial greenhouse (field experiment 1). A, Severity of leaf coverage, $\mathbf{B}$, incidence of leaf shedding, and $\mathbf{C}$, total disease severity of cv. Turkal plants. Total disease severity of cvs. D, Mazurka and E, Kumbia. Plots in the greenhouse were allocated to four minimal nighttime temperatures and marked as $\mathbf{A}(\diamond), \mathbf{B}(\square), \mathbf{C}(\triangle)$, and $\mathbf{D}(\bigcirc)$, where $\mathbf{A}$ had the highest minimal nighttime temperature and $\mathbf{D}$ had the lowest. Bars represent the least significant differences (at $P \leq 0.05$ ) for each date.

TABLE 4. Daily duration (hours) of periods of specific temperature and relative humidity (RH) levels in the greenhouse plots of field experiment 1

\begin{tabular}{|c|c|c|c|c|c|c|c|}
\hline \multirow{2}{*}{\multicolumn{2}{|c|}{$\begin{array}{l}\text { Location (minimum } \\
\text { nighttime temperature) }\end{array}$}} & \multicolumn{3}{|c|}{ Temperature $\left({ }^{\circ} \mathrm{C}\right)$} & \multicolumn{3}{|c|}{$\mathrm{RH}(\%)$} \\
\hline & & $>15$ & $15-20$ & $10-14.9$ and $<14.9$ & $<80$ & $>80$ & $80.1-90$ \\
\hline$A-B^{z}$ & High & $18.7-24.0$ & $12.7-22.7$ & $0.0-5.15$ & $13.8-22.6$ & $7.0-11.0$ & $4.9-13.0$ \\
\hline C-D & Low & $11.4-7.0$ & $2.2-13.0$ & $5.5-11.6$ & $7.8-17.8$ & $10.2-16.2$ & $10.5-15.0$ \\
\hline
\end{tabular}

${ }^{\mathrm{z}}$ The plots along the temperature gradient were marked as A, B, C, and D, where A plots were the most southern and therefore had the warmest nighttime temperatures. 
$\mathrm{RH}$ from 65 to $75 \%$, and temperatures $>25^{\circ} \mathrm{C}$ were noted in these plots. Average nighttime RH and temperature levels in these plots were higher than those of the northern plots. Although RH is expected to decline as temperature increases, positive correlations between RH and temperature have been observed in pepper greenhouses in the region (M. Fuchs, personal communication).

The correlations between microclimate parameters and pepper powdery mildew severity and incidence were calculated. Because the results are similar to those obtained in field experiment 3 , the results of both experiments are presented together (Table 6).
Yields of the northern plots increased gradually over the course of the season whereas the yields of the southern plots increased more quickly, until 140 days after planting. In the northwestern plots, yields increased just as they did in the southern plots, whereas the yields from the northeastern plots didn't begin to increase until 190 days after planting (Fig. 7D). The early yielding northern plots had high levels of disease severity; therefore, these early yields may represent forced ripening.

We evaluated the relationship between disease and yield. Accumulated yield over the whole season and accumulated yield

TABLE 5. Microclimate conditions significantly correlated with powdery mildew on leaves of sweet pepper plants (field experiment 1$)^{z}$

\begin{tabular}{|c|c|c|c|c|c|c|c|c|}
\hline \multirow[b]{2}{*}{ Cultivar } & \multicolumn{4}{|c|}{ Powdery mildew symptoms on attached leaves } & \multicolumn{4}{|c|}{ Leaf shedding } \\
\hline & Temp. $\left({ }^{\circ} \mathrm{C}\right)$ & Corr. & $\mathrm{RH}(\%)$ & Corr. & Temp. $\left({ }^{\circ} \mathrm{C}\right)$ & Corr. & $\mathrm{RH}(\%)$ & Corr. \\
\hline \multirow[t]{2}{*}{ Turkal } & $<15$ & + & $>90$ & + & $10-15$ & + & $>70$ & + \\
\hline & $>25$ & - & $\ldots$ & $\ldots$ & $\ldots$ & $\ldots$ & $>60$ & + \\
\hline Kumbia & $>25$ & - & $>80$ & + & $>15$ & + & $>70$ & + \\
\hline
\end{tabular}

${ }_{\mathrm{z}}$ Temp. $=$ temperature, Corr. $=$ correlation, and $\mathrm{RH}=$ relative humidity. Only significant $(P \leq 0.05)$ negative $(-)$ and positive $(+)$ correlations are shown.
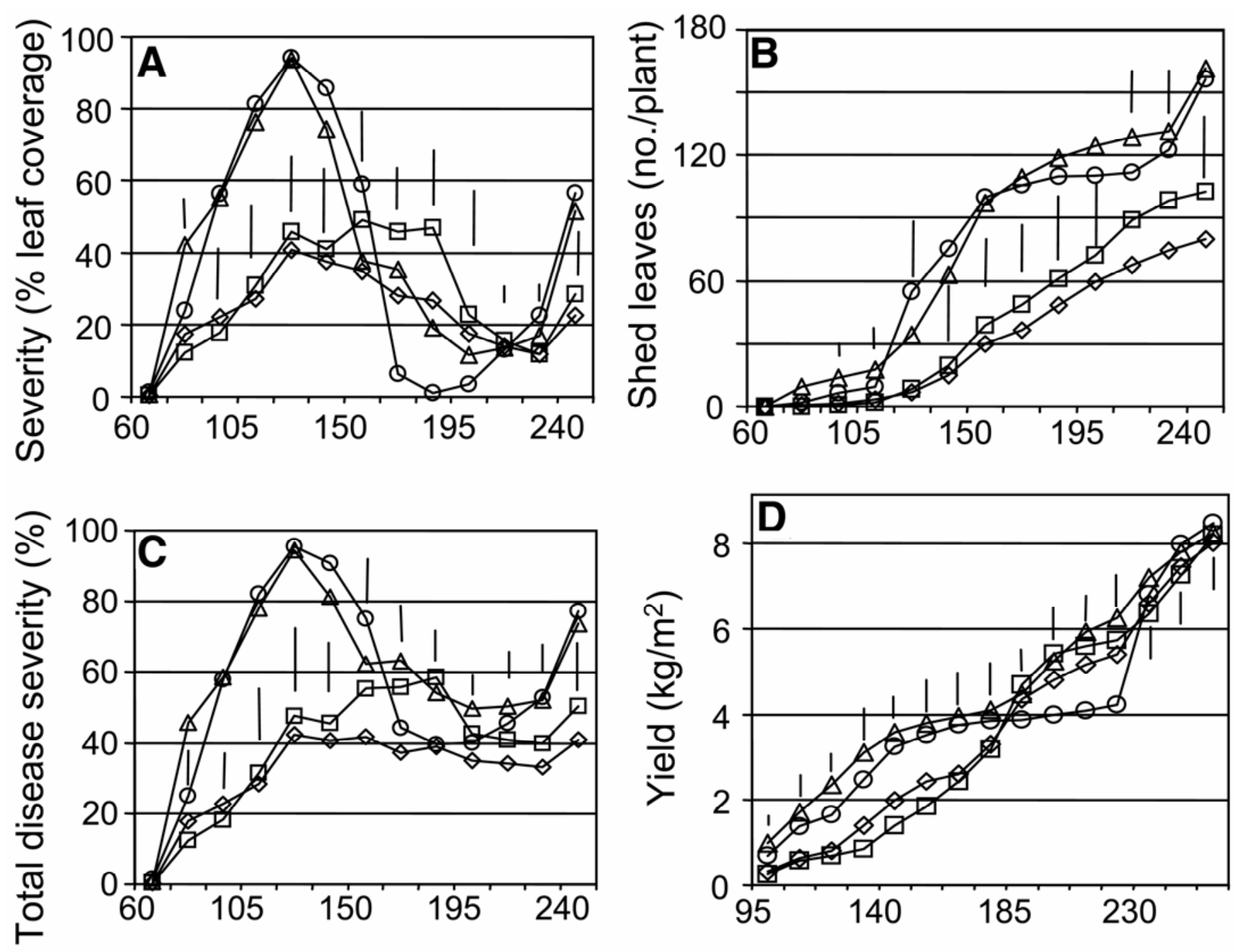

\section{Time (days after planting)}

Fig. 7. Effects of varying minimal nighttime temperature and relative humidity on the development of powdery mildew on sweet pepper plants in a commercial greenhouse (field experiment 2). A, Severity of leaf coverage, B, incidence of leaf shedding, $\mathbf{C}$, total disease severity, and $\mathbf{D}$, total yield of cv. Mazurka plants. Plots were assigned to four climate regions marked as southwest (SW, $\diamond)$, southeast (SE, $\square$ ), northwest (NW, $\triangle$ ), and northeast (NE, $\bigcirc$ ), where minimal nighttime temperatures were $17^{\circ} \mathrm{C}\left(\mathrm{SW}\right.$ and $\mathrm{NW}$ ) and $12^{\circ} \mathrm{C}$ (SE and $\mathrm{NE}$ ), with additional mist (SW and SE) and without mist (NW and NE). Bars represent the least significant differences (at $P \leq 0.05$ ) for each date. 
through the 180 days after planting each were evaluated relative to disease severity. Significant correlations were found only for that period when the disease started to decline in the absence of mature leaves and the presence of young leaves. Total disease (and not leaf coverage or leaf shedding) was negatively correlated with yield in the plots with low minimum nighttime temperatures. This result was not obtained in plots with high night temperature.

Effect of side-wall aeration and greenhouse cover on disease (field experiment 3, 1998-99. Disease developed more slowly in the unheated greenhouses. The first symptoms appeared 70 days after planting and leaves began to fall 90 days after planting. The nature of the polyethylene cover did not affect the disease development. Higher disease severity was observed in the more aerated greenhouses. The disease reached $58 \%$ severity at the end of the season in the IRV 30-mesh treatment (Fig. 8). Because the correlations between microclimate and disease parameters complement the results obtained in field experiment 2, they are presented together in Table 6.

Correlations between the levels of disease and microclimate parameters in experiments 2 and 3 are summarized in Table 7. Leaf coverage by powdery mildew was positively correlated with RH levels of 75 to 95 and 65 to $85 \%$ at 3 to 4 and 1 to 2 weeks before disease evaluation, respectively, and with temperatures $<16^{\circ} \mathrm{C}$. It was negatively correlated with temperatures $>16^{\circ} \mathrm{C}$, daily $\mathrm{RH}$, and dew presence (Table 7 ). Leaf shedding was positively correlated with high temperatures and $\mathrm{RH}<75 \%$, at 1 to 4 weeks before each disease evaluation and also with temperatures $<13^{\circ} \mathrm{C}$ at 3 to 4 weeks before each disease evaluation. Similarly, daytime RH was negatively correlated with leaf shedding (Table 6).

The total yield of the more aerated plots (which had higher levels of disease) was $8.5 \%$ lower than the yield of the lessaerated plots (significant difference at $P \leq 0.05$ ). The weight of the fruit meeting the local market quality requirements was $20 \%$ higher (Table 7). There were negative correlations between export quality yield and powdery mildew leaf coverage, shed leaves, and TDS. On the other hand, a positive correlation was found between the disease parameters and the lower-quality local market yield, indicating that there was a shift from high to low quality due to powdery mildew infection.

Effect of microclimate change on powdery mildew (field experiment 4, 1999-2000). This experiment involved two cultivars in two climate conditions that were rotated in two growth periods (Table 1). Disease was evaluated in greenhouses during the first half of the growth season when the two climate treatments were increased day temperature and unheated (lower) day temperature. The results for the two cultivars were similar; only the Mazurka data are presented in Figure 9. As compared with the low severity of powdery mildew in the greenhouses which were heated during the day, the epidemic developed quickly in the cooler greenhouses, causing high levels of leaf coverage (Fig. 9A) and leaf shedding (Fig. 9B). Consequently, TDS was high
(Fig. 9C). This was reflected in significant yield differences (data not shown).

For the second half of the season, the heated greenhouses (which had not been heated during the first period) each were assigned a minimal night temperatures (Table 1). In these greenhouses, a massive leaf renewal was observed and the new leaves were barely affected by the disease (Fig. 9D and E, left). On the other hand, during the second period, new powdery mildew symptoms were observed in the newly unheated greenhouses. The disease did not decline as expected during this part of the season; it increased at the end of the season (Fig. 9D to F, right). Over the second half of the season, cool nighttime temperatures in the warm-day greenhouses resulted in higher disease levels than in the greenhouses with the same daytime temperatures and warmer nights (Fig. 9D to F).

Climate management for powdery mildew suppression (field experiment 5, 2000-01). The climate treatment was applied when initial disease already had been established in all greenhouses, with disease severity levels at $\approx 20 \%$. Daytime warming by closing the side walls was used until the end of the season, supplemented by night warming during January through March. Once the climate regimes were in place, we noticed a difference in the development of disease; disease was less severe in the warmer greenhouses. In the warm-climate treatment, leaf cover-

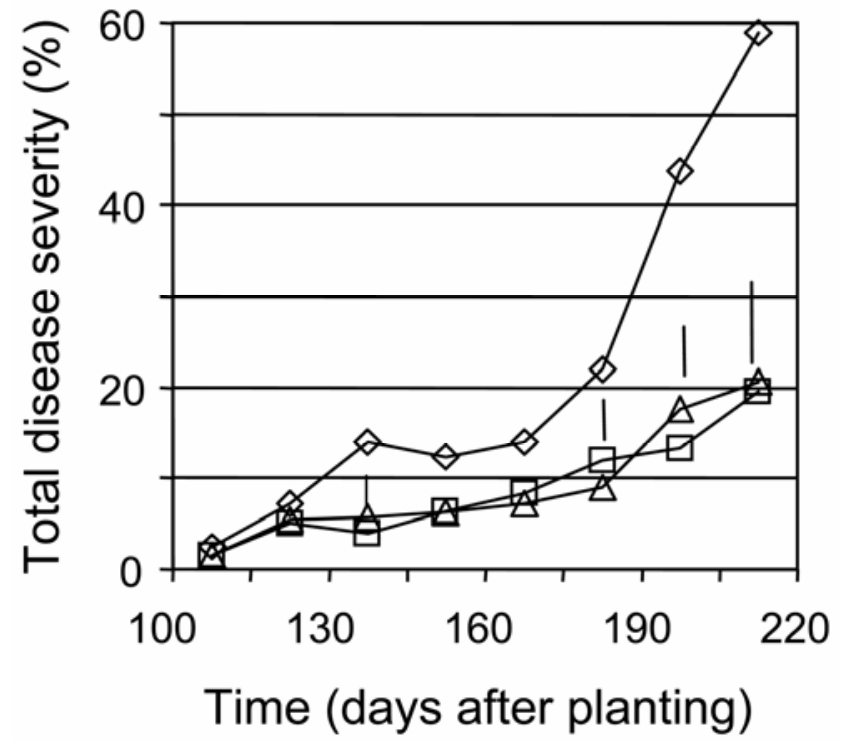

Fig. 8. Effects of roof and sidewall materials on total disease severity for powdery mildew on sweet pepper plants (cv. Mazurka) grown in greenhouses (field experiment 3). Treatments included greenhouses with roofs and side walls with higher ultraviolet (UV) protection of either 30-mesh $(\diamond)$ or 50 mesh $(\square)$ nets and roofs with lower UV protection with 50 -mesh side walls $(\triangle)$. Bars represent the least significant differences (at $P \leq 0.05$ ) for each date.

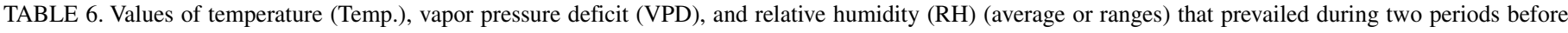
powdery mildew evaluations and significantly $(P \leq 0.05)$ correlated with disease severity and incidence in field experiments 2 and 3

Period of microclimate parameters occurrence before disease evaluation ${ }^{\mathrm{y}}$

\begin{tabular}{|c|c|c|c|c|c|c|c|c|}
\hline \multirow[t]{2}{*}{ Disease parameter } & \multicolumn{4}{|c|}{ During 2 weeks before disease evaluation } & \multicolumn{4}{|c|}{ During 3 to 4 weeks before disease evaluation } \\
\hline & VPD (KPa) & RH $(\%)$ & Temp. $\left({ }^{\circ} \mathrm{C}\right)$ & Dew & VPD (KPa) & $\mathrm{RH}(\%)$ & Temp. $\left({ }^{\circ} \mathrm{C}\right)$ & Dew \\
\hline \multirow[t]{3}{*}{ Leaf coverage } & $<0.5,+^{\mathrm{y}}$ & $65-85,+$ & / & - & $<0.3,+$ & $75-95,+$ & $>15,-$ & / \\
\hline & $\ldots$ & $\ldots$ & $\ldots$ & $\ldots$ & $\ldots$ & $\ldots$ & $<15,+$ & $\ldots$ \\
\hline & $\ldots$ & $\ldots$ & $\ldots$ & $\ldots$ & $\ldots$ & $\ldots$ & $16-22,-$ & $\ldots$ \\
\hline \multirow[t]{4}{*}{ Leaf shed } & $<0.5,-$ & $>65,-$ & $>22,+$ & / & $<0.8,+$ & $75-95,-$ & $>13,<19,-$ & l \\
\hline & $0.6-1.5,+$ & $<75,+$ & $<22,-$ & $\ldots$ & $\ldots$ & $<75,+$ & $>19,<13,+$ & $\ldots$ \\
\hline & Day, $+^{\mathrm{z}}$ & Day, - & Day, + & $\ldots$ & Day, + & Day, - & Day, + & $\ldots$ \\
\hline & Night average, - & $\ldots$ & Night average, - & $\ldots$ & $\ldots$ & $\ldots$ & $\ldots$ & $\ldots$ \\
\hline
\end{tabular}

y Symbols: $+=$ positive correlation, $-=$ negative correlation, and / = no significant correlation.

${ }^{\mathrm{z}}$ Positive correlation $=$ the higher the microclimate parameter, the higher the disease symptom severity or incidence during the day or night. 


\begin{tabular}{|c|c|c|c|c|c|}
\hline \multirow[b]{3}{*}{ Greenhouse cover ${ }^{\mathrm{x}}$} & \multirow[b]{3}{*}{ Side net (mesh) } & \multicolumn{4}{|c|}{ Yield } \\
\hline & & \multicolumn{2}{|c|}{ Overall } & \multirow{2}{*}{$\frac{\text { Grade A }}{\text { Weight }^{\mathrm{z}}}$} & \multirow{2}{*}{$\frac{\text { Grade B }}{\text { Weight }^{\mathrm{z}}}$} \\
\hline & & Number ${ }^{\mathrm{y}}$ & Weight $^{\mathrm{z}}$ & & \\
\hline IRV & 30 & $26,524 \pm 1,896$ & $4,188 \pm 242$ & $3,161 \pm 204$ & $1,027 \pm 228$ \\
\hline IRV & 50 & $25,740 \pm 2,100$ & $4,276 \pm 262$ & $3,457 \pm 201$ & $819 \pm 74$ \\
\hline IRR & 50 & $27,266 \pm 1,613$ & $4,316 \pm 296$ & $3,447 \pm 307$ & $869 \pm 50$ \\
\hline
\end{tabular}

$\mathrm{x}$ IRV = polyethylene containing increased amount of UV absorbent; IRR $=$ regular polyethylene cover.

${ }^{y}$ Number of fruits $/ 1,000 \mathrm{~m}^{2} \pm \mathrm{SE}(P \leq 0.05)$.

${ }^{\mathrm{z}}$ Fruit weight in $\mathrm{kg} / 1,000 \mathrm{~m}^{2} \pm \mathrm{SE}(P \leq 0.05)$.
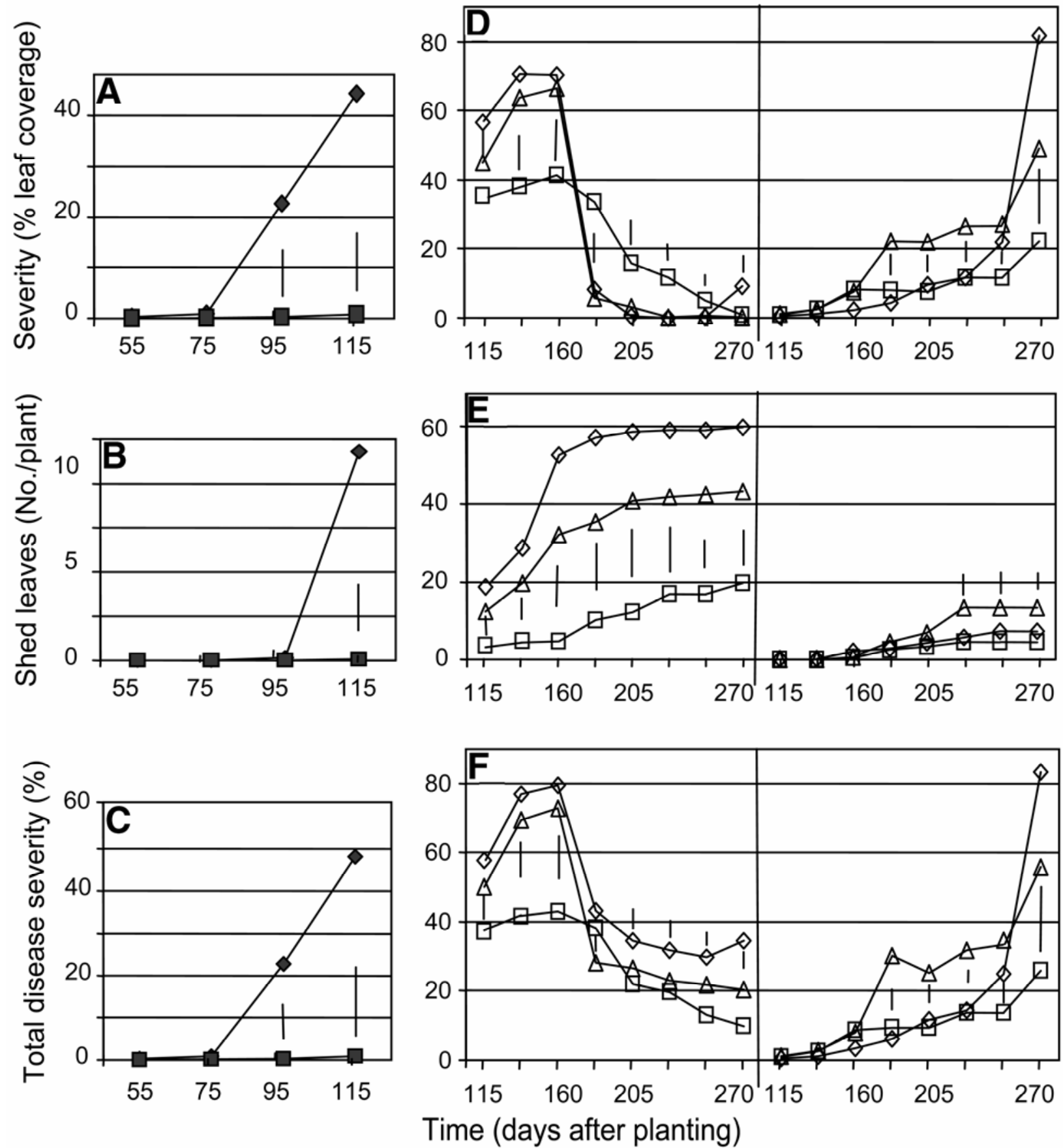

Fig. 9. Effect of midseason climate change on the development of powdery mildew on sweet pepper plants (cv. Mazurka) in a commercial greenhouse (field experiment 4). A and D, Severity of leaf coverage, $\mathbf{B}$ and $\mathbf{E}$, incidence of leaf shedding, and $\mathbf{C}$ and $\mathbf{F}$, total disease severity were evaluated. The season was divided into two periods. During the first period (A to C), plots which were heated during the day (匹) were compared with plots which were not heated ( $)$ ). None of these plots were heated at night. Those plots which were unheated during the first half of the season were heated during the second half (D to F, left) and those plots which had been heated during the first half of the season were not heated during the second half (D to F, right). During the second half of the season, specific nighttime minimal temperatures $\left(13\right.$ to $14[\diamond], 17$ to $18[\square]$, and 20 to $22^{\circ} \mathrm{C}[\triangle]$ ) were assigned to subplots within each of the two larger treatments. Bars represent the least significant differences (at $P \leq 0.05$ ) for each date. 
age reached $30 \%$ and the general disease severity was $33 \%$. At the same time, the cool-climate plants reached infection levels of $88 \%$ leaf coverage and $91 \%$ general disease severity (data not shown). Disease-climate relations were analyzed (Table 8).

Powdery mildew may affect yield accumulation in various ways (Table 9). We tested the effect of disease on the amount of photosynthesizing leaves. Negative effects may be caused by leaf coverage by disease symptoms and by leaf shedding. The number of flowers was counted as well. It was found that (i) higher disease levels were correlated with lower flower number and with higher leaf shedding, (ii) higher flower count and lower leaf shedding both were associated with higher yields, and (iii) higher levels of disease were correlated with the lower general yield in the plot. These correlations were not obtained in the first period, when the general disease severity reached $25 \%$ (Table 9).

\section{DISCUSSION}

The development of a plant disease requires a susceptible host tissue, a compatible pathogen, and the prevalence of suit- able environmental conditions for the plant-pathogen interaction. In the present work, we studied parameters related to all of these components as they relate to the development of pepper powdery mildew. Conidial germination of L. taurica occurred over a wide temperature range $\left(10\right.$ to $\left.37^{\circ} \mathrm{C}\right)$, was optimal at $20^{\circ} \mathrm{C}$, but was particularly low at the most extreme temperatures (Fig. 1). These findings are similar to those of Butt (1), Celio and Hausbeck (3), and Reuveni et al. (17). The viability of the conidia declines as temperature increases; following a 6-h incubation at $40^{\circ} \mathrm{C}$, only a small proportion of the conidia remained alive (Fig. 3). Temperatures of 15 to $25^{\circ} \mathrm{C}$ were optimal for leaf colonization by L. taurica (Table 2). At temperatures $>25^{\circ} \mathrm{C}$, the germination of conidia is slow, their survival decreases, and colonization of host tissue by the surviving conidia is lower than at the optimal range of 15 to $25^{\circ} \mathrm{C}$. The effects of temperature on leaf colonization and disease development were studied in growth-chamber experiments under variable conditions (Tables 2 and 3; Fig. 4). The highest disease levels were on leaves after incubation at 15 to $20^{\circ} \mathrm{C}$ (Fig. 4). This occurred despite the fact that tissue colonization was higher at 20 to $25^{\circ} \mathrm{C}$, pre-

TABLE 8. Microclimate-powdery mildew of sweet pepper relationships in field experiment 5 (2000-01) where warm climate regimes were established in the greenhouses $^{\mathrm{x}}$

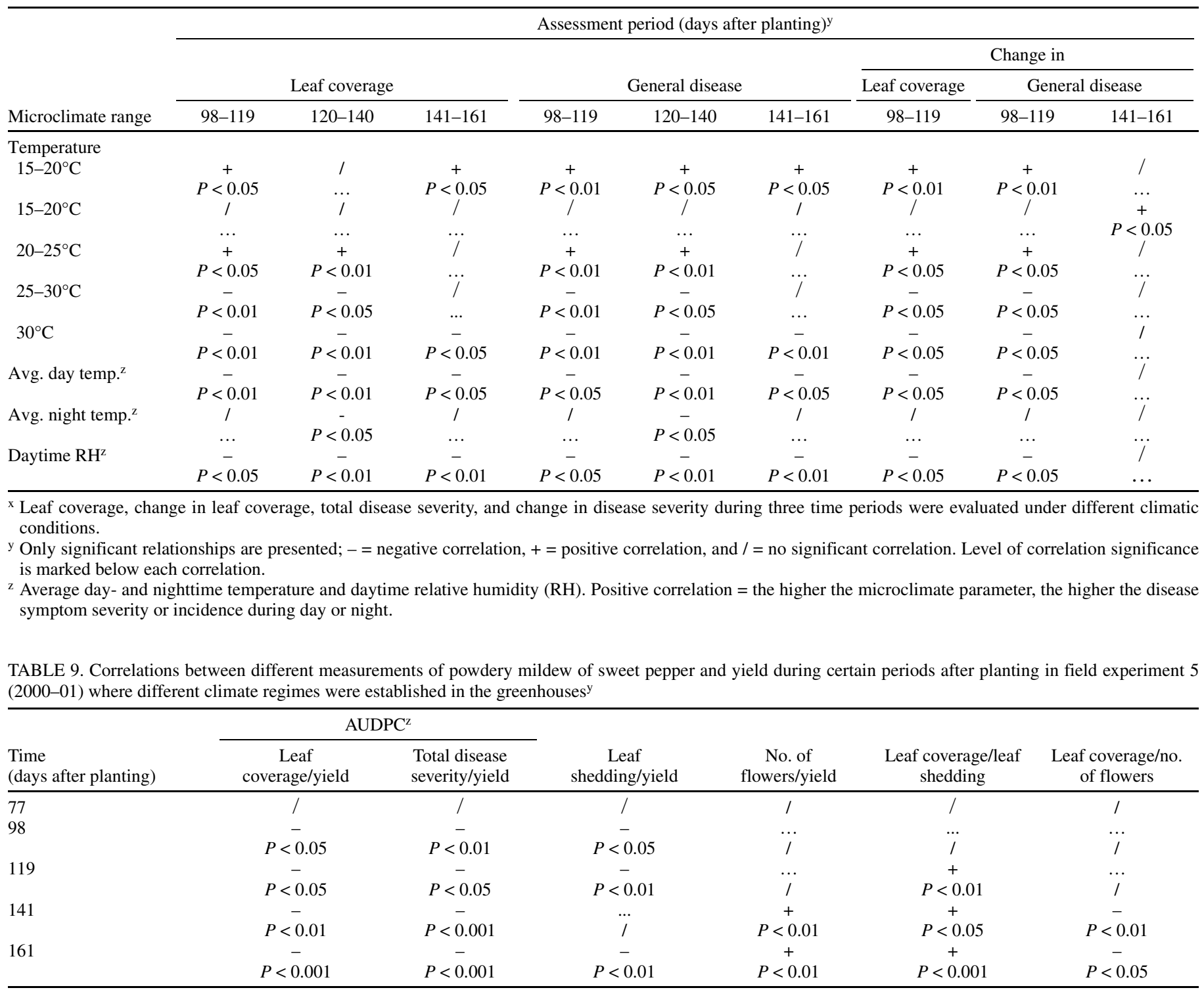

y Only significant relationships are presented; $-=$ negative correlation, $+=$ positive correlation, and $/=$ no significant correlation. Level of correlation significance is marked below each correlation.

${ }^{\mathrm{z}}$ Area under the disease progress curve. 
sumably because conidiation was suppressed at the higher temperatures.

Germination increased as $\mathrm{RH}$ increased and was optimal at 75 to $85 \%$ RH (Fig. 2). This confirms previously published findings $(2,19)$. In our laboratory work, RH did not affect later stages of pathogen development. This contrasts with the behavior of this pathogen in tomato, as reported by Guzman-Plazola et al. (9). They reported that temperatures of $\geq 30^{\circ} \mathrm{C}$ were deleterious for conidial germination, germ tube elongation, and disease development. Lesion growth and the rate of disease progress were significantly higher at 20 than at $25^{\circ} \mathrm{C}$. Low $\mathrm{RH}$ levels (20 to $40 \%$ ) reduced conidial germination and lesion growth, accelerated host tissue death, and reduced disease progress. Intermediate $\mathrm{RH}$ levels (50 to 70\%) increased conidial germination and optimized disease development, as long as temperatures were maintained within favorable limits. High RH levels ( 80 to $90 \%$ ) were favorable for the germination of conidia; however, continued exposure to these conditions limited lesion growth and disease progress.

We performed five greenhouse experiments under commercial growing conditions in which we studied the effects of certain climatic factors on disease development. The data collected in the field experiments were used to draw conclusions regarding the effects of temperature and RH on disease development. Summarizing the significant correlations over the four seasons of field studies, it can be concluded that the severity of powdery mildew on leaf surfaces is positively correlated with duration of temperatures between 10 and $15^{\circ} \mathrm{C}$ and $\mathrm{RH}$ of 85 to $95 \%$, and with average nighttime RH. (Tables 5, 6, and 8). Conversely, leaf shedding was positively correlated with duration of temperatures $>20^{\circ} \mathrm{C}$ and $<13{ }^{\circ} \mathrm{C}$ and duration of $\mathrm{RH}<75 \%$. It also was positively correlated with the average daytime temperatures. Leaf shedding was negatively correlated with duration of temperatures of 13 to $19^{\circ} \mathrm{C}$ and 75 to $95 \% \mathrm{RH}$ (Tables 5, 6, and 8). These findings are similar to those of Reuveni and Rotem (18), who reported decreased disease at $>30^{\circ} \mathrm{C}$.

The effects of these microclimate parameters on disease development also should be reflected in the epidemics observed in the various experiments. Indeed, disease was more severe in plots with lower temperatures and higher RH in field experiments 1 and 2 (Figs. 6 and 7). In the third field experiment, disease also was more severe in the cooler and more humid greenhouses, which, in this experiment, had more sparse net on the side walls (30-mesh nets) (Fig. 8).

The fact that long periods of high temperatures are associated with lower disease levels led us to consider the development of a cropping system in which greenhouse heating would help prevent the development of powdery mildew epidemics. Indeed, increasing nighttime temperatures reduced disease in field experiments 4 and 5 (Fig. 9). However, intensive nighttime heating is not practical. Daytime warming of the greenhouse was very effective in suppressing epidemic development, as observed in field experiments 4 and 5 (Fig. 9). Thus, it can be concluded that disease levels can be kept low not only by increasing nighttime but also by increasing daytime temperatures. Moreover, a midseason shift from a cool daytime greenhouse climate to warm daytime climate halted epidemic development, and a change from a warm climate to a more moderate climate resulted in a dramatic increase in disease levels, as shown in field experiment 4 (Fig. 9). GuzmanPlazola et al. (9) found that short daily periods (two or three daily exposures of at least $2 \mathrm{~h}$ ) of high temperatures $\left(35^{\circ} \mathrm{C}\right)$ suppressed disease development by 70 to $92 \%$ in tomato. This concurs with our observation that long periods of high temperatures can suppress powdery mildew in pepper.

The decline in disease severity as a result of higher nighttime temperatures cannot be explained by a direct temperature effect on the pathogen. L. taurica optimally germinates and infects at temperatures lower than those achieved by daytime warming (Figs. 1 and 4; Tables 2 and 3). As we (Tables 5, 6, and 8) and
Schnathordt (19) have reported, L. taurica powdery mildew develops best at $\mathrm{RH}$ levels $>75 \%$. Therefore, the effect of higher nighttime temperatures actually may reflect the concurrent reduction in RH. Manipulation of the daytime temperatures resulted in temperatures $>25^{\circ} \mathrm{C}$. At these temperatures, conidia germinate slowly, infection is less frequent, and the life spans of individual conidia of $L$ taurica are relatively short. It also may be that plants exposed to high temperatures become less susceptible to infection.

The onset of flower development traditionally has been regarded as the time of disease initiation on plants (16). However, we observed natural epidemics that began earlier. This difference in the timing of the appearance of symptoms may be related to differences in cultivars, the shift from open field to greenhouse cropping, or differences in planting dates that may affect either host susceptibility or the microclimate conditions for infection. In any case, as described in earlier works, once symptoms appear, they generally are most severe on older leaves (Fig. 5) (16). Over the course of the epidemic during the long winter cropping season, older, severely infected leaves are shed and new leaves develop on new branches. At this point, a second wave of symptoms appears (Figs. 6 and 7). During this second wave, disease is no longer less severe in the higher, younger leaves. This secondary period of springtime epidemic development will pose a threat only to those crops that are kept for 10 months. Cultivars may differ in susceptibility to powdery mildew, as shown in Figures 5 and 6 for the three cultivars tested in field experiment 1 . However, later in the growing season, these cultivar differences were minimized. In later years, cv. Mazurka, on which low to moderate levels of disease were observed during the beginning of the first season, suffered from significant powdery mildew disease. Therefore, none of the examined cultivars appeared to possess any genetic resistance to powdery mildew.

The use of selective polyethylene greenhouse roofs to filter UV irradiation has been mentioned as a potential means for slowing the development of plant diseases, including powdery mildews (8). In this study, UV-absorbing polyethylene was not associated with any reduction in the severity of pepper powdery mildew (Fig. 8).

Field experiments 2 through 5 revealed a negative correlation between yield accumulation and disease. In one experiment, high disease levels were positively correlated with low-quality yield. Palti (16) generalized the L. taurica-yield relationship, saying that yield losses in pepper occur when severe disease occurs in pepper. In the present work, disease was associated with yield losses when severe epidemics occurred. This was due to significant loss of photosynthetic ability of the plants when a vast number of leaves were shed. In such cases, fruit development was inhibited and the number of flowers per plant was reduced (Table 9), at least partially due to flower drop.

The present study demonstrates that one out of all tested means of cultural control offers potential to suppress pepper powdery mildew (i.e. daytime warming of the greenhouse by closing the side walls). Results suggest that control of the high temperature limit should be implemented while aerating the greenhouse to eliminate excessive humidity in order to prevent the development humidity-favored diseases. The combination of daytime greenhouse warming with other means of powdery mildew control was tested and will be published elsewhere.

\section{ACKNOWLEDGMENTS}

This research was supported by the Chief Scientist of the Israeli Ministry of Agriculture, The Israeli Board of Vegetable Growers, and the Dutch-Israeli Agricultural Research Fund (DIARP). We thank A. Dik (The Netherlands), Y. Posalski, E. Taari, H. Yekhezkel, M. Targerman, D. Shmuel, E. Matan, A. Salpoi, L. Cordoba, E. Dayan, M. Fuchs, and Y. Cohen from R\&D South, Besor Research Station, for their help and cooperation. 


\section{LITERATURE CITED}

1. Butt, D. J. 1978. Epidemiology of powdery mildews. Pages 51-77 in: The Powdery Mildews, D. M. Spencer, ed. Academic Press Inc. Ltd., London.

2. Caesar, J. C., and Clerk, G. C. 1985. Germinability of Leveillula taurica (powdery mildew) conidia obtained from water-stressed pepper plants. Can. J. Bot. 63:1681-1684.

3. Celio, G. J., and Hausbeck, M. K. 1998. Conidial germination, infection structure formation, and early colony development of powdery mildew on poinsettia. Phytopathology 88:105-113.

4. Clerk, G. C., and Ayesu-Offei, E. N. 1967. Conidia and conidia germination in Leveillula taurica (Lev.) Arn. Ann. Bot. 31:749-754.

5. Correll, J. C., Gordon, T. R., and Elliott, V. J. 1987. Host range, specificity, and biometrical measurements of Leveillula taurica in California. Plant Dis. 71:248-251.

6. Dik, J. A., Ceglarska, E., and Ilovai, Z. 1999. Sweet Peppers. Pages 473485 in: Integrated Pest and Disease Management in Greenhouse Crops. R. Albajes, M. L. Gullino, J. C. Van Lenteren, and Y. Elad, eds., Kluwer Academic Publishers, Dordrecht, the Netherlands.

7. Diop-Bruckler, M. 1989. Dévelopement de Leveillula taurica en funcion des facteurs climatiques et sensibilité de Capsicum annиum a différents stades végétatifs. (French). J. Phytopathol. 126:104-114.

8. Elad, Y. 1997. Effect of filtration of solar light on the production of conidia by field isolates of Botrytis cinerea and on several diseases of greenhouse crops. Crop Prot. 16:635-642.

9. Guzman-Plazola, R. A., Davis, R. M., and Marois, J. J. 2003. Effects of relative humidity and high temperature on spore germination and development of tomato powdery mildew (Leveillula taurica). Crop Prot. 22:1157-1168.
10. Homma, Y., Arimoto, Y., Takahashi, H., Ishikawa, T., Matsuda, I., and Misato, T. 1980. Studies on pepper powdery mildew. I. Conidial germination, hyphal elongation and hyphal penetration on pepper leaf. Ann. Phytopathol. Soc. Jpn. 46:140-149.

11. Homma, Y., Takahashi, H., Arimoto, Y., Ishikawa, T., Matsuda, I., and Misato, T. 1981. Studies on pepper powdery mildew II. Conidiophore emergence and conidial formation on pepper leaf. Ann. Phytopathol. Soc. Jpn. 47:143-150.

12. Jones, W. B., and Thompson, S. V. 1987. Source of inoculum, yield, and quality of tomato as affected by Leveillula taurica. Plant Dis. 71:266-268.

13. Kunoh, H., Kuhno, M., Tashiro, S., and Ishizaki, H. 1979. Studies of the powdery-mildew fungus, Leveillula taurica, on green pepper. II. Light and electron microscopic observation of the infection process. Can. J. Bot. 57:2501-2508.

14. Millard, P. J., Roth, B. L., Thi, H. P. T., Yue, S. T., and Haugland, R. P. 1997. Development of the FUN-1 family of fluorescent probes for vacuole labelling and viability testing of yeasts. Appl. Environ. Microbiol. 63:2897-2905.

15. Palti, J., 1959. Oidiopsis diseases of vegetable and legume crops in Israel. Plant Dis. Rep. 43:221-226.

16. Palti, J. 1988. The Leveillula mildews. Bot. Rev. 54:423-535.

17. Reuveni, R., Perl, M., and Rotem, J. 1974. The effect of Leveillula taurica on leaf abscissions in peppers. Phytopathol. Z. 80:79-84.

18. Reuveni, R., and Rotem, J. 1973. Epidemics of Leveillula taurica on tomatoes and peppers as affected by the conditions of humidity. Phytopathol. Z. 76:153-157.

19. Schnathorst, W. C. 1965. Environmental relationships in the powdery mildews. Annu. Rev. Phytopathol. 3:343-366.

20. Shtienberg, D., and Dreishpoun, J. 1991 Suppression of Alternaria leaf spot in Pima cotton by systemic fungicides. Crop Prot. 10:381-385. 